\title{
Universiteit
}

Leiden

The Netherlands

\section{What's in a line? Is partition a solution to civil war?}

Sambanis, N.; Schulhofer-Wohl, J.

\section{Citation}

Sambanis, N., \& Schulhofer-Wohl, J. (2009). What's in a line? Is partition a solution to civil war? International Security, 34(2), 82-118. doi:10.1162/isec.2009.34.2.82

Version: $\quad$ Not Applicable (or Unknown)

License: $\quad$ Leiden University Non-exclusive license

Downloaded from: $\quad$ https://hdl.handle.net/1887/121951

Note: To cite this publication please use the final published version (if applicable). 
What's in a Line?

Is Partition a Solution to Civil War?
Nicholas Sambanis and Jonah SchulhoferWohl

T he debate over territorial partition as a solution to civil war is highly politically relevant. At the height of the Iraqi civil war in 2006 and 2007, faced with intensifying violence against civilians, mistrust among the main Sunni, Shiite, and Kurdish groups, and bleak prospects for state building, policymakers and analysts turned to ideas about partitioning the country. ${ }^{1}$ War-induced partitions and partitioninduced wars continue to be prominent features in international security-two recent examples being the de facto partition of Kosovo from Serbia in 1999 followed by international recognition of Kosovo's independence in 2008, and the August 2008 war between Russia and Georgia following the latter's invasion of the separatist region of South Ossetia.

Partition promises a clean and simple solution to war-but does it work? From a policy standpoint, the answer to this question is critical because peacebuilding after civil war is difficult and often fails. Civil wars are hard to end and when they do end, they often restart within a few years. The instability of power sharing after many civil wars has led researchers to propose territorial partition with or without formal recognition of sovereignty (i.e., de jure or de facto separation) as a stable solution to separatist or ethnic civil wars and a clear-cut way to create self-enforcing peace. ${ }^{2}$ Arguments for partition rely on claims that ethnic identities are hardened by war, making interethnic cooperation difficult and increasing the risk that individuals will be targeted for vio-

Nicholas Sambanis is Professor of Political Science at Yale University. Jonah Schulhofer-Wohl is a Ph.D. candidate in Yale's Department of Political Science. The supplement with coding information and additional analysis referred to in this article can be downloaded from http://pantheon.yale.edu/ ns237/index/research/ Partition2.pdf.

The authors thank Kenneth Scheve, Jas Sekhon, and Jack Snyder for comments and useful discussions.

1. On why the internal violence in Iraq qualifies as a civil war, see Nicholas Sambanis, "It's Official: There Is Now a Civil War in Iraq," New York Times, July 23, 2006. On partition as a way to end that violence, see Edward P. Joseph and Michael E. O'Hanlon, "The Case for Soft Partition in Iraq," Brookings Analysis Paper, No. 12 (Washington, D.C.: Saban Center for Middle East Policy, Brookings Institution, June 2007); Chaim Kaufmann, "Living Together after Ethnic Killing: In Theory, in History, and in Iraq Today," in Mia Bloom and Roy Licklider, eds., Living Together after Ethnic Killing: Exploring the Chaim Kaufmann Argument (London: Routledge, 2006), pp. 277-320; and Ivan Eland, Partitioning for Peace: An Exit Strategy for Iraq (Oakland, Calif.: Independent Institute, 2009).

2. The most prominent argument is Chaim Kaufmann, "Possible and Impossible Solutions to Ethnic Conflict," International Security, Vol. 20, No. 4 (Spring 1996), pp. 136-175; and Chaim Kaufmann, "When All Else Fails: Ethnic Population Transfers and Partitions in the Twentieth Century," International Security, Vol. 23, No. 2 (Fall 1998), pp. 129-156.

International Security, Vol. 34, No. 2 (Fall 2009), pp. 82-118

(C) 2009 by the President and Fellows of Harvard College and the Massachusetts Institute of Technology. 
lence simply because of their ethnic group membership. Thus, by physically separating ethnic groups in conflict, partition promises to reduce the risk of continued or escalating violence.

This conjecture has intuitive appeal. Partition also has costs, however, as it changes political boundaries and forcibly relocates populations. It is therefore important to assess the risks and benefits of partition, though academic research on this topic has remained frustratingly equivocal. We argue that the premises underlying this deceptively simple conjecture are questionable and that the empirical evidence in favor of partition is weak. Most studies advocating partition rely on a few illustrative cases rather than on systematic hypotheses tests, and large- $n$ quantitative studies often reach conflicting conclusions. One study analyzing all civil wars from 1945 to 1999, written after the first wave of case study-based pro-partition articles, finds little, if any, support for the claim that partitions reduce the risk of civil war recurrence. ${ }^{3}$ Yet a 2007 comprehensive empirical study on partition reanalyzes the same data and finds that de jure partitions have a strong pacifying effect after civil war. ${ }^{4}$

To move this debate forward, we take stock of the most prominent arguments for and against partition, identify the source of disagreements in empirical studies, and demonstrate the fragility of pro-partition empirical results. We establish just how crucial data coding issues are in this debate, how thin the evidentiary basis is for most pro-partition claims, and how methodological difficulties limit what scholars can learn from any quantitative study on partition. We show that, on the basis of available evidence, partition does not have the pacifying effect that its advocates claim. However, we also identify limitations inherent in any quantitative study of partition. Thus, to learn more about partition's effects, it is necessary to supplement quantitative analysis with detailed attention to data issues, knowledge of the historical and political context of the cases, and rigorous theory building. In contrast to other studies, this article does not claim to present incontrovertible evidence that partition does or does not work. Rather, we interpret our empirical results as offering suggestive evidence and find that partition does not work in general and that the set of conditions under which it is likely to work is very limiting. We use our empirical results to scrutinize the logic and premises underlying common theoretical claims in favor of partition and identify the main unanswered questions in the partition debate. We conclude with suggestions on how to further this debate.

3. Nicholas Sambanis, "Partition as a Solution to Ethnic War: An Empirical Critique of the Theoretical Literature," World Politics, Vol. 52, No. 4 (July 2000), pp. 437-483.

4. Thomas Chapman and Philip G. Roeder, "Partition as a Solution to Wars of Nationalism: The Importance of Institutions," American Political Science Review, Vol. 101, No. 4 (November 2007), pp. 677-691. 


\section{Taking Stock of the Empirical Literature on Partition}

The best-known argument for partition is elaborated in two influential articles by Chaim Kaufmann, who claims that partition is a good solution if it is impossible for groups to live together in an ethnically heterogeneous state. ${ }^{5}$ The argument is based on the theoretical claims that ethnic power sharing is particularly unstable because ethnic identities, which harden during war and are thought to be more easily identifiable than other social identities, make individuals vulnerable to targeting for violence in the event of a failure of the peace process. Partition can help, according to Kaufmann, because it resolves the ethnic security dilemma: by dividing territory and physically separating warring groups (through population transfers), it reduces the threat that each ethnic group poses for the other. ${ }^{6}$

Partition is conceptually distinct from population transfers, though in most cases, it is accompanied by substantial sorting of populations. In this article, we define partition broadly as a civil war outcome that results in territorial separation of a sovereign state. This includes cases of de jure partition, in which a new internationally recognized state is formed as a result of a successful secession (e.g., Bangladesh, Croatia, and Eritrea); and de facto partition, in which there is divided sovereignty over the territory of a single internationally recognized state (Abkhazia and South Ossetia in Georgia and the Turkish Republic of Northern Cyprus in Cyprus). ${ }^{7}$ The degree of population transfers is not a part of our preferred definition. ${ }^{8}$

5. Kaufmann, "Possible and Impossible Solutions to Ethnic Conflict"; and Kaufmann, "When All Else Fails."

6. According to the security dilemma argument, partition will have a pacifying effect only if populations are nearly entirely separated within a new set of borders, but sovereignty is not necessary. See Kaufmann, "Possible and Impossible Solutions to Ethnic Conflict," pp. 161-162. In later arguments, Kaufmann joins Alexander B. Downes to argue that the new borders must be accorded legal sovereignty. See Kaufmann, "Living Together after Ethnic Killing"; and Alexander B. Downes, "The Problem with Negotiated Settlements to Ethnic Civil Wars," Security Studies, Vol. 13, No. 4 (Summer 2004), pp. 230-279.

7. After a bloody civil war, East Pakistan seceded from Pakistan and became Bangladesh in 1971; in June 1991 Croatia declared independence from Yugoslavia and was officially recognized by the United Nations in the spring of 1992; and following the overthrow of the Ethiopian government in 1991 after a decade and a half of civil war, Eritrea's demands for a referendum on independence were granted, with Eritrea becoming independent in May 1993. In other cases of separation, however, international recognition was not achieved: the 1983 declaration of the formation of the Turkish Republic of Northern Cyprus, following the Turkish invasion that resulted in occupation of about 40 percent of the territory of the island of Cyprus, has not yet been internationally recognized. Similarly, although both Abkhazia and South Ossetia declared their independence from Georgia following their secession and brief civil wars in the early 1990s, they too failed to achieve international juridical recognition.

8. Because we want to examine the relationship between partitions and war recurrence, and be- 
Arguments about the impossibility of living together after ethnic war implicitly assume that ending conflicts between ethnic groups, as opposed to any other social group, is particularly difficult. Anecdotal evidence of spontaneous sorting of ethnic groups into defensible enclaves during violent escalation of political conflicts provides prima facie support for this argument.

A cursory glance at the world, however, suggests that redrawing borders, with or without substantial physical separation of people, is often unsuccessful in reducing the risk of war recurrence. Soon after it declared independence from Yugoslavia in June 1991, ${ }^{9}$ Croatia's government was at war with Serb minorities in Eastern Slavonia. After Eritrea seceded from Ethiopia in 1993, the two countries fought a bloody territorial war from 1998 to 2000 and were again on the brink of war in 2005, even after a complete separation of their populations. The de facto secession of Somaliland from Somalia in 1991 seems to have benefited Somaliland, but Somalia is a failed state with a resurgent civil war and recursive secessions in Puntland and Sool. India and Pakistan have fought three wars since they were partitioned in 1947, and a low-level insurgency has been taking place in Kashmir for the past twenty years. The partition of Palestine in 1948 was, by most standards, not a great success. Other civil wars that involved ethnic groups in conflict and threatened state collapse have ended without partition, as in South Africa and Guatemala, or in the conflict between Tigreans and Amharans in Ethiopia. ${ }^{10}$

These historical examples challenge pro-partition arguments, but other examples may suggest that partition, under certain conditions, might work. After Cyprus was repartitioned in 1974 and Greeks and Turks were forcibly separated, there was no further war in Cyprus or between Greece and Turkey; and after West and East Pakistan were partitioned in 1971, there was no war between Bangladesh (formerly East Pakistan) and Pakistan. Nevertheless, these outcomes may well be idiosyncratic. India stands between Bangladesh and Pakistan, creating a long buffer zone that is hard to cross in renewed hos-

cause peaceful partitions do not create the same risks and tensions that violent partitions do, we exclude all peaceful partitions, such as the creation of the Former Yugoslav Republic of Macedonia in 1992, Czechoslovakia in 1993, and Singapore in 1965.

9. Croatia became a member state of the United Nations on May 22, 1992. See United Nations General Assembly, "Admission of the Republic of Croatia to membership in the United Nations," A/RES/46/238 (May 22, 1992).

10. The internal violence in South Africa is not recognized as a civil war in all data sets, but it meets the coding criteria for civil war that we use for the period from 1976 to 1994. Guatemala saw two periods of civil war combined with a genocide of indigenous people, from 1966 to 1972 and 1978 to 1994 (or 1997, by some accounts). Tigreans challenged the Amharan-dominated Ethiopian state in a fight over control of the government from 1978 to 1991 and that war overlapped with a longer secessionist war between Eritreans and the Ethiopian state. 
tilities. Peace in Cyprus was partly enforced by the superior military strength of Turkey and NATO's watchful eye.

How, then, is it possible to assess the empirical record when cases of partition are so few and differences among them potentially large? Most studies of partition, especially those in favor of it, use illustrative evidence from selective case studies and do not directly confront large- $n$ empirical results. Alexander Downes, for example, draws on the history of partition in Palestine and the wars in Bosnia and Kosovo to argue that partition should be preferred to attempts to preserve multiethnic states through power sharing or to separation of ethnic groups with autonomy. ${ }^{11}$ Carter Johnson makes a security dilemma argument that partitions work only if there is near-complete ethnic separation, ${ }^{12}$ but he only compares those cases to cases of partition with incomplete population separation, implicitly assuming that outcomes under partition are significantly different from outcomes without partition.

These shortcomings make a recent pro-partition argument by Thomas Chapman and Philip Roeder, which is based on cross-national data over a period of about fifty years, particularly important. ${ }^{13}$ By reanalyzing data compiled by Nicholas Sambanis, ${ }^{14}$ Chapman and Roeder present a new propartition argument loosely based on what they call an "institutional bargaining" model. In short, they argue that partitions that result in the creation of new sovereign states with international recognition (henceforth referred to as de jure partition) reduce the likelihood of any escalation in hostilities in the short run (two years after the end of a civil war), as compared to both de facto separation of territories without formal recognition and regional autonomy agreements.

Given that Chapman and Roeder's article is the most recent and most comprehensive empirical assessment of the effects of partition to date, a good way to build cumulative knowledge is to proceed with a replication and extension of their analysis. We focus on the main question that the literature on partition has addressed: whether or not partition reduces the risk of civil war recurrence. ${ }^{15}$ We begin with the data, models, and methods used by Chapman and

11. Alexander B. Downes, "The Holy Land Divided: Defending Partition as a Solution to Ethnic Wars," Security Studies, Vol. 10, No. 4 (Summer 2001), pp. 58-116.

12. Carter Johnson, "Partitioning to Peace: Sovereignty, Demography, and Ethnic Civil Wars," International Security, Vol. 32, No. 4 (Spring 2008), pp. 140-170.

13. Chapman and Roeder, "Partition as a Solution to Wars of Nationalism."

14. Sambanis, "Partition as a Solution to Ethnic War."

15. We eschew discussion of other outcomes, such as postwar democratization or economic recovery following partition. In the aftermath of civil war, we often see both democratization and higher economic growth. The causes are unclear and require new theorizing that would shift the discus- 
Roeder and later introduce new data and apply alternative estimation methods. We show that pro-partition empirical results are the result of data-coding mistakes and use of the wrong universe of cases. The effect of partition depends on which cases are included, how partition is coded, and the level of violence that scholars want to explain.

Chapman and Roeder's institutionalist argument is that partitions should outperform all other solutions to civil wars over competing nation-state projects (henceforth referred to as "nationalist civil wars") because they simplify the nature of bargaining between elites of the secessionist region and elites of the predecessor state, reducing opportunities for violence escalation. The authors define partition narrowly to include only the formation of a new sovereign state following civil war-7 cases from 1945 to $2000 .{ }^{16}$ They distinguish partitions from territorial separation without sovereignty (what we call de facto partitions). Only one case of partition in their list led to a failure of the peace (Palestine), so the results from any empirical study using these data will be naturally sensitive to the small number of cases. In this context, seemingly minor data issues have big substantive implications. We demonstrate this by focusing on three crucial data questions. First, how should we code the dependent variable? Second, what is the relevant universe of cases? Third, when should we code a partition?

Let us start with the first question. The dependent variable in most of the institutionalist literature is war recurrence. Chapman and Roeder instead analyze a different dependent variable- the survival of peace. Their variable indicates "whether the parties avoided re-escalating their conflict with one another for at least 2 years after the end of the civil war." 17 Survival of peace combines lower-level armed conflict, large-scale human rights abuses, and civil war oc-

sion away from an assessment of the pacification effect of partition. Sambanis discusses some evidence for a democratizing effect of partition but notes that the association is unclear because democracy data are not available for de facto partitioned regions. Chapman and Roeder use "time to democratization" as an outcome, but this is an ambiguous concept. See Sambanis, "Partition as a Solution to Ethnic War"; and Chapman and Roeder, "Partition as a Solution to Wars of Nationalism." Rapid democratization in countries with weak institutions and no prewar experience with democracy might not be a positive outcome and could increase the risk of a return to war. For a recent argument, see Edward D. Mansfield and Jack Snyder, Electing to Fight: Why Emerging Democracies Go to War (Cambridge, Mass.: MIT Press, 2005).

16. Chapman and Roeder, "Partition as a Solution to Wars of Nationalism." The cases on their list are the partitions of Eritrea from Ethiopia, Pakistan from India, Bangladesh from Pakistan, Namibia from South Africa, Israel from Palestine, and Bosnia and Croatia from Yugoslavia. By contrast, the original data set compiled by Sambanis has 21 "civil war related" partitions out of 125 cases of civil war combining de jure and de facto partitions as well as cases where partition happens during or at the start of the war. See Sambanis, "Partition as a Solution to Ethnic War." 17. Chapman and Roeder, "Partition as a Solution to Wars of Nationalism," p. 883. 
currences; it is therefore a broad category capturing what we might call "residual" violence. War recurrence is coded as one of three outcomes in a different categorical variable-the extent of the peace. ${ }^{18}$

In table 1, we replicate Chapman and Roeder's key model (model 4, table 3 in the article). This is a probit model with survival of peace as the dependent variable, regressed on partition, separation (de facto partition), and autonomy (regional autonomy agreements and other territorial power sharing), as well as some controls (war duration, war deaths, the size of the government's armed forces, per capita gross domestic product [GDP], and the presence of peace operations). The effects of the three variables of interest-partition, separation, and autonomy-are all compared to the effects of unitary systems, which is the omitted category in this regression. The replication is exact, and partition is shown to be the only outcome with a statistically significant pacifying effect (i.e., there is a positive correlation with survival of the peace).

On closer inspection, however, Chapman and Roeder's results do not support the authors' own institutionalist argument. The results from this model actually show that the effect of partition is not statistically different from the effect of separation and autonomy. ${ }^{19}$ Moreover, partition does not have a pacifying effect when we look at civil war recurrence alone. We see this in column 2 of table 1, where all the covariates are the same as in the model in column 1, but the dependent variable is now war recurrence. Here the dependent variable is binary and is coded 1 in the 16 cases of return to war in Chapman and Roeder's extent of the peace variable. In this model, the effect of partition is diminished by almost half and is no longer statically significant.

Now we consider the relevant cases for these comparisons. According to Chapman and Roeder, partition should have a positive effect only after wars over "competing nation-state projects." Chapman and Roeder define these as wars based on "a claim that a particular population has a right to a state of its own" - that is, wars between "incompatible national identities" or what one might call nationalist wars. ${ }^{20}$ Their empirical analysis is inconsistent with that definition, however, because it is based on all civil wars that were classified as having an "ethnic" component by Sambanis, ${ }^{21}$ but not all ethnic

18. Survival of the peace is a binary variable coded 1 if there was no further conflict reescalation and 0 otherwise. Extent of the peace is coded 0 if there was a return to war, 1 if there was some residual violence but no war, and 2 if there was no residual violence.

19. The $p$-value for a $t$-test of equality of coefficients for partition and de facto separations is 0.07 ; and it is 0.11 for the coefficients of separation and autonomy.

20. Chapman and Roeder, "Partition as a Solution to Wars of Nationalism," p. 679.

21. Sambanis, "Partition as a Solution to Ethnic War." 
wars are nationalist wars. ${ }^{22}$ Nationalist wars might be reasonably defined as wars between the state and an ethnic group that perceives itself as a nation and fights for secession or a greater degree of self-determination. A close reading of the cases reveals that out of the 72 ethnic wars that Chapman and Roeder analyze, only 39 cases could have been classified as nationalist wars. Thus only those 39 cases should have been included in a test of their theory, as the other cases were not wars over self-determination or separatism. ${ }^{23}$ In column 3 in table 1, we show results from Chapman and Roeder's model with the analysis restricted to those 39 cases. The coefficient for partition is no longer statistically significant $(p=0.12$ ). Because the number of cases is so small, the results are naturally sensitive, so we bootstrap standard errors and find that parameter estimates are less robust with the bias-corrected confidence interval for the coefficient of partition ranging from -3.16 to 7.74 (see supplement, pp. $45-46){ }^{24}$

Finally, we consider which cases should be coded as partitions. Chapman and Roeder classify as separations those cases that others have coded as partitions. This has significant implications for their results. ${ }^{25}$ An example is the recoding of the two Croatian wars. Sambanis codes a civil war in Yugoslavia in 1991 in connection with Croatia's secession. The Croatian victory marks the end of the war, according to the rules for coding war events. That victory resulted in Croatia's successful secession and was quickly followed by another

22. For example, Burma in 1968 (Communist Party Rebellion), Algeria in 1992, Somalia in 1988, and Nigeria in 1980 (Maitatsine rebellion) are usually not thought of as nationalist wars, but they are included in Chapman and Roeder's analysis. Moreover, it is often unclear which wars are ethnic. Sambanis's list was based on ethnic war classifications in the State Failure Task Force. See Daniel C. Esty, Jack A. Goldstone, Ted Robert Gurr, Barbara Harff, Marc Levy, Geoffrey D. Dabelkko, Pamela T. Surko, and Alan N. Unger, State Failure Task Force Report: Phase II Findings (McLean, Va.: Science Applications International Corporation, July 31, 1998). To check robustness, we recoded all cases using a clearer coding rule and detailed explanations of coding. Wars are classified as ethnic if the majority of the parties recruit members within a single ethnic group or if they form alliances only within that group, or along a single cleavage dimension that excludes parties fighting on the opposite side. We use this alternative list for robustness tests but preserve Chapman and Roeder's list of ethnic wars in our reanalysis of their data.

23. We define self-determination broadly and include wars that appear to be more about regional autonomy and less about secession (e.g., the Sikh rebellion in India and the Baganda rebellion in Uganda). Moreover, out of the 58 secessionist wars that we have coded since 1945 (including ongoing wars), 22 could be considered nonethnic and these would be excluded if the effects of partition are only assessed on the category of ethnic wars.

24. These results retain residual violence as the dependent variable. A model of war recurrence estimated on separatist wars shows partition not statistically significant and regional autonomy now predicts success (peace) perfectly (results not shown).

25. A number of other ad hoc coding changes by Chapman and Roeder influence the results but are not discussed here. Notably, Chapman and Roeder drop some ethnic wars from Sambanis's data set (such as the war between the Turkish state and the Kurds and the Philippines against the Moro Islamic Liberation Front), though these should be included according to their coding rules. 
Table 1. Replication and Extension of Chapman and Roeder's 2007 Model of Partition

\begin{tabular}{|c|c|c|c|c|}
\hline & $\begin{array}{l}\text { Survival of } \\
\text { Peace }\end{array}$ & $\begin{array}{l}\text { War } \\
\text { Recurrence }\end{array}$ & $\begin{array}{l}\text { Survival of } \\
\text { Peace } \\
\text { (separatist } \\
\text { wars only) }\end{array}$ & $\begin{array}{l}\text { Survival of } \\
\text { Peace (all wars } \\
\text { in Chapman and } \\
\text { Roeder with } \\
\text { Croatia fixed) }\end{array}$ \\
\hline Partition & $\begin{array}{l}2.434 \\
(2.73) * *\end{array}$ & $\begin{array}{c}1.347 \\
(1.42)\end{array}$ & $\begin{array}{c}1.652 \\
(1.55)\end{array}$ & $\begin{array}{c}1.373 \\
(2.05)^{*}\end{array}$ \\
\hline Separation & $\begin{array}{c}0.819 \\
(1.58)\end{array}$ & $\begin{array}{c}0.545 \\
(0.90)\end{array}$ & $\begin{array}{c}0.379 \\
(0.61)\end{array}$ & $\begin{array}{c}0.731 \\
(1.43)\end{array}$ \\
\hline Autonomy & $\begin{array}{l}-0.385 \\
(-0.65)\end{array}$ & $\begin{array}{c}0.344 \\
(0.49)\end{array}$ & $\begin{array}{l}-0.512 \\
(-0.76)\end{array}$ & $\begin{array}{l}-0.419 \\
(-0.71)\end{array}$ \\
\hline WarDuration & $\begin{array}{l}0.085 \\
(2.89)^{* *}\end{array}$ & $\begin{array}{c}0.050 \\
(1.52)\end{array}$ & $\begin{array}{c}0.092 \\
(2.23)^{*}\end{array}$ & $\begin{array}{l}0.071 \\
(2.62)^{* *}\end{array}$ \\
\hline WarDeaths & $\begin{array}{l}-0.21 \\
(-2.62) * *\end{array}$ & $\begin{array}{l}-0.168 \\
(-1.82)\end{array}$ & $\begin{array}{l}-0.078 \\
(-0.75)\end{array}$ & $\begin{array}{l}-0.167 \\
(-2.17)^{*}\end{array}$ \\
\hline ArmedForces & $\begin{array}{l}-0.271 \\
(-0.7)\end{array}$ & $\begin{array}{l}0.756 \\
(1.42)\end{array}$ & $\begin{array}{l}-0.193 \\
(-0.41)\end{array}$ & $\begin{array}{l}-0.307 \\
(-0.79)\end{array}$ \\
\hline GDPperCapita & $\begin{array}{l}-0.129 \\
(-1.34)\end{array}$ & $\begin{array}{c}-0.186 \\
(-1.74)^{+}\end{array}$ & $\begin{array}{l}-0.125 \\
(-1.12)\end{array}$ & $\begin{array}{l}-0.072 \\
(-0.79)\end{array}$ \\
\hline PeaceOperations & $\begin{array}{c}0.153 \\
(0.37)\end{array}$ & $\begin{array}{l}0.360 \\
(0.85)\end{array}$ & $\begin{array}{l}0.329 \\
(0.58)\end{array}$ & $\begin{array}{c}0.205 \\
(0.52)\end{array}$ \\
\hline Constant & $\begin{array}{l}1.784 \\
(1.92)\end{array}$ & $\begin{array}{c}2.293 \\
(2.09)^{*}\end{array}$ & $\begin{array}{c}0.413 \\
(0.46)\end{array}$ & $\begin{array}{l}1.342 \\
1.49\end{array}$ \\
\hline Observations & 72 & 72 & 39 & 72 \\
\hline$x^{2}$ & 22.30 & 10.37 & 11.81 & 16.68 \\
\hline
\end{tabular}

SOURCE: Thomas Chapman and Philip G. Roeder, "Partition as a Solution to Wars of Nationalism: The Importance of Institutions," American Political Science Review, Vol. 101, No. 4 (November 2007), pp. 677-691.

Probit regression; z-scores in parentheses.

${ }^{+}$significant at $0.10 ;{ }^{*}$ significant at $0.05 ; *$ * significant at 0.01

war from 1992 to 1995 pitting Croatia's government against Serbs from the Krajina region, who attempted to secede. This is a case of a partition failing to end the violence. Chapman and Roeder recode this as a case of no partition after the first war and code a partition as occurring only after the second Croatian war (in 1995). Thus, the war from 1992 to 1995 is "charged" to the lack of partition following the war in 1991, and the successful peace after 1995 is "credited" to a partition that never happened after that war. ${ }^{26}$ When we correct the coding of Croatia, we find that the coefficient of partition in the survival of peace model in Chapman and Roeder's analysis is reduced by 44 percent and the estimate is barely significant (column 4 , table 1). The

26. Historical details to support our coding are discussed in the supplement, pp. 5-7. 
coefficient of partition in an ordered logit model with extent of the peace as the dependent variable is no longer statistically significant. ${ }^{27}$

The coding of this case is worth a close look, given its consequences. Croatia first declared independence from Yugoslavia on June 25, 1991, but under a cease-fire agreement brokered by the European Community at the beginning of July, it suspended independence for a three-month period with the Brioni accord signed on July $7,1991 .^{28}$ No states officially recognized Croatia until the end of 1991-Iceland doing so on December 20 and Germany on December 23-although negotiations during that period culminated in official European Community recognition of Croatia in mid-January $1992 .{ }^{29}$ On May 22, 1992, Croatia joined the United Nations. ${ }^{30}$ The fighting between Croatian forces and the Yugoslav People's Army (Jugoslovenska Narodna Armija, or JNA) and its ethnic Serbian allies in Croatia is separable from the second war in Croatia for the secession of the ethnically Serbian Krajina region and took place in a new sovereign state. Croatia signed a cease-fire with the JNA on January 3, 1992, effectively marking the end of the JNA's war over Croatia's secession. ${ }^{31}$ In our data set, that war is coded as ending in rebel victory in December 1991 with the first international recognitions of Croatia as an independent state. The Croatia-JNA agreement paved the way for the deployment of UN peacekeeping troops, and despite some violations, represented the basis of the conclusion of the war. The JNA completed withdrawing its forces from Croatian territory on October 20, $1992 .{ }^{32}$ Croatia's victory in seceding from Yugoslavia, particularly after the Croatian government was internationally recognized, marks a clear separation between this war and the Krajina Serbs' war of secession against the Croatian government, as "continuing armed conflict against a new government implies a new civil war."33

27. The coefficient drops from 3.29 (1.29) to 1.63 (1.03). See the supplement, p. 52.

28. Alan Hanson, "Croatian Independence from Yugoslavia, 1991-1992," in Melanie C. Greenberg, John H. Barton, and Margaret E. McGuinness, eds., Words over War: Mediation and Arbitration to Prevent Deadly Conflict (Lanham, Md.: Rowman and Littlefield, 2000), pp. 76-108.

29. United Press International, "Iceland Recognizes Slovenia, Croatia," December 20, 1991; and Nada Buric, "Germany Recognizes Slovenia and Croatia," Associated Press, December 23, 1991. Germany established formal ties with Croatia on January 15, 1992, but in a letter to Croatian President Tudjman on December 23, 1991, it granted official recognition. Additionally, Estonia, Latvia, and Lithuania had already recognized Croatia.

30. United Nations General Assembly, "Admission of the Republic of Croatia to Membership in the United Nations," 86th Plenary Meeting (A/RES/46/238), May 22, 1992.

31. Norman Cigar, "Croatia's War of Independence: The Parameters of War Termination," Journal of Slavic Military Studies, Vol. 10, No. 2 (June 1997), p. 34.

32. John F. Burns, "Croats Return to Stronghold on Adriatic," New York Times, December 10, 1992.

33. Nicholas Sambanis, "What Is Civil War? Conceptual and Empirical Complexities of an Operational Definition," Journal of Conflict Resolution, Vol. 48, No. 6 (December 2004), p. 830. The change 
The second event corresponds to the war between Krajina Serbs, who wanted to secede from Croatia, and the Croatian government. Although the Yugoslav Army assisted Krajina Serbs, the tables turned in the second war, with Serbs trying to secede from Croatia rather than Croatians trying to secede from Yugoslavia. The war from 1992 to 1995 is also clearly separable from the first in terms of the combatants. Whatever assistance the JNA may have provided the Krajina Serbs, the war was fought between their local units, organized as the Army of Serbian Krajina (Vojska Srpske Krajine, or VSK) and the Croatian Army. ${ }^{34}$ Lower-level armed conflict started in 1992 and 1993, but vio-

in government criterion is important to highlight because of other authors' coding of the wars in Croatia. Johnson, for example, does not count a partition of Croatia in 1992 "because of the difficulty of categorizing it as a war end." See Johnson, "Partitioning to Peace," p. 155. In other respects, however, he uses the original data set compiled by Sambanis that counts that partition. In support of his recoding decision, Johnson notes ongoing hostilities between "Yugoslavian/Serb and Croatian forces" including "the Serb siege of Dubrovnik and the Croat siege of Bihač," and fighting between the Croatian army and the army of the Republic of Serbian Krajina, giving the examples of operations in Maslenica and Zadar in January 1993 and in the Medak Pocket in September 1993, as well as the Croatian army's Operation Flash in May 1995. Of the fighting that took place during this period, only fighting between the VSK and the Croatian army can reasonably be considered to represent a possible continuation of the 1991 war. The international recognition of the Croatian government represents an end to the war of secession. If casualty thresholds were met in the fighting between the JNA and the Croatian army after this point, we might code this as a new war. It would qualify as an international war, however, rather than as an internal one (the International Criminal Tribunal for the Former Yugoslavia considered the war after October 8, 1991, to be an international conflict, even before the distinction we are making about the international recognition of the Croatian government). Quoted in Mile Bjelajac and Ozren Žunec, "The War in Croatia, 1991-1995," Scholar's Initiative Round Table Report: The Hague: Institute for Historical Justice and Reconciliation (October 20, 2007), p. 13. It is also unclear whether the fighting between the JNA and the Croatian army following Croatia's recognition can be considered a war in its own right in terms of casualty thresholds. The siege of Dubrovnik, for example, is particularly well documented, following an extensive field study by the United Nations. According to the UN, "Possibly as many as 88 civilians were killed between September 1991 and the end of December 1992." Most of the civilian casualties occurred in the fall of 1991, with approximately 20 between December 1991 and 1992. See United Nations, "Annex XI.A: The Battle of Dubrovnik and the Law of Armed Conflict," in S/1994/674/Add.2, December 28, 1994; and United Nations Security Council, Final Report of the United Nations Commission of Experts Established Pursuant to Security Council Resolution 780 (1992). Local officials are quoted in a journalistic account as estimating 180 combined military and civilian casualties for the duration of the siege. See Adam LeBor and Michael Evans, "Yugoslav Commander Threatens to Halt Croatian Withdrawal," Times, October 20, 1992. The later engagements quoted by Johnson, "Partitioning to Peace," were between the Croatian army and the VSK, as discussed above. Again, because of the victory of the Croatian government in its secession from Yugoslavia, these cannot be considered part of an ongoing war from 1991. The fighting in Bihač cited by Johnson did not even take place on the territory of Croatia, but was part of Croatia's participation in the war in Bosnia and Herzegovina. Furthermore, any assistance that the JNA gave the VSK during the period does not imply that the war at this point was not intra-state, setting aside the criterion of a change in government.

34. See Milan Vego, "The Army of Serbian Krajina," Jane's Intelligence Review, Vol. 5, No. 10 (October 1993), p. 493; and Norman Cigar, "The Serb Guerrilla Option and the Yugoslav Wars: Assessing the Threat and Crafting Foreign Policy," Journal of Slavic Military Studies, Vol. 17, No. 3 (September 2004), p. 513. 
lence was low intensity for most of that period, rising to the level of civil war in $1995 .{ }^{35}$ Krajina Serbs were not successful in separating from Croatia; thus, at the conclusion of that war, we do not include this in our list of partitions that were the outcome of civil war. ${ }^{36}$

This brief reanalysis suggests that the most prominent article to date laying out a pro-partition argument makes inferences that are heavily influenced by data coding decisions (in addition to methodological errors). Furthermore, the differences we found between models of war recurrence and models of lowerlevel violence are instructive: if institutional arguments in favor of partition are correct, then we would expect to find that partitions reduce the risk of another civil war-not just lower-level violence-because the proposed mechanism is that partition reduces opportunities for violence reescalation. Thus our results are inconsistent with the proposed theoretical mechanism of partition as a way to defuse conflicts and prevent escalation, because we find that partition does not have an effect on escalation, just on lower-level violence. This finding prompts us to consider more closely the foundations of competing theoretical claims for partition.

\section{Theoretical Foundations}

How can the literature on partition move forward, given that there are inherent limitations to quantitative analysis? Case histories alone do not solve the problem, as they are also prone to the same limitations and more. One solution is to use detailed case knowledge in combination with quantitative analysis. Case knowledge can help by improving the quality of data used in quantitative studies. This is something we do in this study, returning to basic questions about data coding: What is the relevant universe of cases for tests of the effects of partition? What is the meaning of partition? What types of outcomes is partition likely to affect? These are data questions, and answering them helps us

35. See coding notes from Sambanis, "What Is Civil War?" pp. 814-858, for details on the coding of start and end dates for this conflict. See also Martin Špegelj, "The First Phase, 1990-1992: The JNA Prepares for Aggression and Croatia for Defence," in Branka Magaš and Ivo Žanič, eds., The War in Croatia and Bosnia-Herzegovina 1991-1995 (London: Routledge, 2001), pp. 14-40. "Operation Storm" of August 1995, in which Croatian troops invaded Krajina, was the largest land offensive in Europe since the conclusion of World War II.

36. If a line of partition is established in one war and the line is redrawn in a new war, both cases could be coded (as in Cyprus, where the 1964-67 partition line was redrawn and expanded following the 1974 invasion). In India/Kashmir, by contrast, the second Kashmir war should not be coded as a case of new partition. In a version of the partition variable that identifies all partitioned countries regardless of when the civil war-related partition took place after the end of the war, these cases could be included. 
to avoid some of the pitfalls of other quantitative studies on partition, but these data questions also have clear theoretical implications. For example, an assumption of security dilemma-based arguments for partition is that partition is relevant only as a solution to ethnic war, and the premise underlying that assumption is that ethnic wars are harder to end and require the physical separation of groups, whereas this is not true for other types of civil war. By looking at the data questions we identified above more closely, we can rethink such assumptions and premises. In this section, we scrutinize the premises and assumptions of the two dominant theoretical arguments about partition: the security dilemma and institutional transformation. This helps us to identify the main theoretical questions that should structure a new research program on the effects of partition.

\section{THE ETHNIC SECURITY DILEMMA}

Partition advocates turn to Barry Posen's ethnic security dilemma to explain why partition would reduce violence during or after ethnic war. ${ }^{37}$ According to Posen, when there is no impartial state policing, when the state is weak or collapsing, and when there is an outbreak of political violence in a multiethnic state, ethnic groups become responsible for their own security. The risk of violence escalation is high when what Posen calls a "tactical offensive advantage" dominates. ${ }^{38}$ The offensive advantage is influenced by, among other things, political geography. In areas with mixed ethnic settlements, groups that are surrounded by potentially hostile neighbors are at risk. Their coethnics have a narrow window of opportunity to intervene in their defense, generating incentives for preemptive war. These defensive motives for violence are paradoxical because they stem from the tactical military advantage for the offense: whoever uses force first has a better chance of winning. As a result, each group attempts to cleanse its territory of large numbers of potentially hostile ethnic groups, a dynamic that leads to the rapid escalation of violence in a preemptive war.

37. Barry R. Posen, "The Security Dilemma and Ethnic Conflict," Survival, Vol. 35, No. 1 (Spring 1993), pp. 27-47. Among those who use the logic of the security dilemma to support pro-partition arguments, see Kaufmann, "Possible and Impossible Solutions to Ethnic Conflict"; Downes, "The Holy Land Divided"; Johnson "Partitioning to Peace"; and Erik Melander, "The Geography of Fear: Regional Ethnic Diversity, the Security Dilemma and Ethnic War," European Journal of International Relations, Vol. 15, No. 1 (March 2009), pp. 95-124.

38. Because in ethnic conflict military technology is fairly rudimentary, it is group cohesion and solidarity that underlies the offensive advantage. It also stems from the difficulty of defending against attacks on civilians, who are particularly vulnerable when they are a small fraction of the population and are geographically isolated. 
The security dilemma is attractive to partition advocates because of the importance it places on the role of political geography to generate incentives for violence. Partition would remove the tactical offensive advantage if there is near-complete physical separation and is therefore a tidy solution to a decidedly untidy problem. Partition advocates, however, do not fully consider all of the conditions that Posen specifies as influencing the intensity of the security dilemma in addition to geography.

Even if it were true that ethnic "mixing" generates a security dilemma, it is not reasonable to expect the security dilemma to be equally intense under all possible demographic settlement patterns in countries with the same overall level of ethnic heterogeneity. For example, if populations form large islands or homogeneous villages, the level of security risk is likely different from a situation with ethnic intermingling down to the neighborhood level.

Partition advocates promote a blunt application of the security dilemma logic that relies heavily on two elements of the theory: the claim that ethnic power sharing is particularly unstable and the related claim that ethnic identity is easily identifiable, making targeting of individuals for violence easier after ethnic war. But Posen's theory has another key condition, which is typically omitted from standard partition arguments based on the security dilemma: the presence of powerful coethnics in a neighboring state is a key component of the escalation logic of the security dilemma in Posen's original formulation of the theory, whereas partition advocates claim that the escalation of violence depends chiefly on domestic political geography. According to Posen, the intensity of the security dilemma is diminished if groups "have large numbers of nearby brethren who form a powerful state, which could rescue them in the event of trouble." 39 Yet against the logic of partition advocates, this implies that neighboring states can both deter and catalyze an escalation of violence regardless of demographics.

Cyprus is a good case to illustrate this point. In 1963 a small civil war occurred in Cyprus when Greek Cypriots tried to change the power-sharing arrangement with Turkish Cypriots based on the 1960 consititution. The violence resulted in an incomplete partition of the island in 1964, with Turkish Cypriots occupying small parts of territory that were outside the control of the government. That partition did not homogenize the territories sufficiently, and there was a return to violence in 1967 and even greater violence in 1974, which ultimately resulted in a complete partition of Cyprus in that year. Partition advo-

39. Posen, "The Security Dilemma and Ethnic Conflict," p. 108. 
cates, such as Johnson, point to the 1964 incomplete partition to argue that partitions resolve the security dilemma only if there is near-complete ethnic separation. ${ }^{40}$ The case is inconsistent with this interpretation, however, though it is consistent with the overlooked component of Posen's theory, as the level of ethnic mixing did not hold the key to the intensity of violent conflict. Interethnic violence in Cyprus stopped almost entirely after the incomplete partition of 1964, and the level of partition gradually increased from 1964 to 1967. Violence from 1968 until 1974 was only intra-Greek, as extremists from the EOKA B group (Ethniki Organosi Kyprion Agoniston B) targeted moderates who supported a negotiated settlement with the Turks. ${ }^{41}$ Consistent with Posen's argument, Turkey's superior military power provided deterrence. In 1964 Turkey credibly threatened to invade if Turkish Cypriots were attacked, deterring the escalation of the Greek-Turkish conflict. By contrast, the flare-up in 1974 and eventual complete partition was the direct result of external intervention-a coup staged by a new radical group of military officers from Greece, to which Turkey responded with an invasion. The mechanism of reescalation was external intervention, not the preemptive, indiscriminate use of violence claimed by partition advocates. ${ }^{42}$

Cases such as Cyprus suggest that ethnic power sharing need not be inherently unstable, and that if there is conflict escalation, it is often the result of external intervention and not inherently the country's ethnic demography. The focus on ethnic demography is based on assumptions about the fixity of ethnic identity and the ease of ethnic identification, and these assumptions underpin the position that partition is potentially useful only in ethnic wars. Yet these are unexamined assumptions that are often flawed in the context of most civil wars.

The ethnic security dilemma applies only under conditions of state weakness, and the argument boils down to a credible commitment problem. Commitment problems, however, could arise after all civil wars-both ethnic and nonethnic. Any minority group will feel unsafe as long as it relies on the majority-dominated state for protection. The theory of credible commitment

40. Johnson, "Partitioning to Peace," p. 158.

41. Michael W. Doyle and Nicholas Sambanis, Making War and Building Peace: United Nations Peace Operations (Princeton, N.J.: Princeton University Press, 2006), pp. 257-280.

42. On the history of the Cyprus conflict from 1964 to 1974, see Polyvios G. Polyviou, Cyprus: Conflict and Negotiation, 1960-1980 (London: Duckworth, 1980); Michael E. Dekleris, Kypriako, 1972-1974: E teleftea efkeria [Cyprus problem, 1972-1974: The last opportunity] (Athens: Ekdotiki Estia, 1981); Nikos Kranidiotes, Anochyrote Politeia: Kypros, 1960-1974 [Indefensible state: Cyprus, 1960-1974], vols. 1-2 (Athens: Estia, 1985); and Glafcos Clerides, My Deposition, vols. 1-4 (Nicosia: Aletheia, 1989-92). 
indicates that any power sharing will be noncredible because of the risk that the more powerful party will renege on its promises and attack the weaker party. ${ }^{43}$ Thus, an argument for ethnic partition must explain why postwar interethnic political bargains are less credible than power sharing between any social groups. If partition solves the commitment problem by simplifying institutional bargaining and creating defensible borders, then its benefits should extend to all wars, not just ethnic wars. Interestingly, there is at least one case of nonethnic partition that has done fairly well (China-Taiwan). There are particularities to all cases, but if nonethnic partitions work just as well as ethnic ones, then what does that suggest about the use of the ethnic security dilemma as the theoretical foundation of pro-partition arguments? The implication of this argument for empirical analyses is that ethnic wars do not make up the natural universe of cases for tests of the effects of partition, given that partitions have also occurred after nonethnic wars (China-Taiwan) and nonsecessionist wars (Somaliland in Somalia) and partition is only one of several ways through which the credible commitment problem might be addressed.

A case might be made to separate the study of partitions following ethnic and nonethnic wars if the "ease of targeting" argument is correct. But the argument still remains an untested assumption. To limit the application of the security dilemma to ethnic wars is to assume that ethnic identities are unchanging and uniquely identifiable, thus making targeting of individuals who share the ethnic group's attributes easy based on visual identification. The reality is that in most civil wars violence is not based on visual identification, but rather on local knowledge of individuals' political allegiances, so it is equally likely that local knowledge exists about individuals' political beliefs and affiliations to any number of social groups. ${ }^{44}$ It follows that security dilemmas can arise in any situation where there is local knowledge of social identities and not only in ethnic conflicts. Thus, if partition works to resolve the ethnic security dilemma, why would it not also work to resolve security dilemmas in other postwar situations? If the mechanism through which partition works to resolve security dilemmas is the creation of political units that are governed by elites that can credibly commit to protect the security of people living in those units, then why would partition be applicable only to ethnic wars?

43. Robert Powell, "War as a Commitment Problem," International Organization, Vol. 60, No. 1 (January 2006), pp. 169-203.

44. For an example from the Greek civil war, see Stathis N. Kalyvas, The Logic of Violence in Civil War (Cambridge: Cambridge University Press, 2006), who establishes that there was nearcomplete knowledge of individual political allegiances at the village level such that switching sides was not feasible. 
An objection might be that complex patterns of economic interdependence between the actors make partition impractical in nonethnic civil wars. Although this might be true in the idealized case of a class-based revolution, where capital fights labor and physically separating the two makes little sense, in reality we also find such interdependencies in ethnic and secessionist wars (think of class-based rebellions in societies where ethnic cleavages map on to class cleavages; or of separatist wars in countries where most of the country's wealth is territorially concentrated in a region dominated by one ethnic group). Moreover, in most cases of nonethnic wars-as in the wars in Sierra Leone, Greece, Colombia, and Afghanistan-political cleavages and war factions cut across social classes and across professions in complicated ways that make partition with voluntary population transfers just as plausibly effective (in theory) as in an ethnic war.

The discussion above raises some objections to the fundamental premises underlying security dilemma arguments in favor of partition, but we must note that empirical studies to date have not provided a full test of the security dilemma. A full test of the theory is not possible for two reasons: first, the theory is not sufficiently well specified; and second, the data needed for such a test are lacking. The literature needs further theoretical refinement to identify the conditions under which partition might work, and the theory needs to be more precise in stipulating a population threshold of residual minorities below which the security dilemma disappears and the precise demographic settlement pattern that is expected to exacerbate the security dilemma (e.g., is it as risky to live in fully integrated neighborhoods as it is in homogeneous neighborhoods in a mixed city?). The data required for such tests might also be collected through new research efforts that are driven by better theory. To properly test the importance of settlement patterns for the intensity of the security dilemma, researchers would require data on the settlement patterns of all ethnic groups at the village or neighborhood level across the territory of all civil war countries over time.

\section{EFFECT OF INSTITUTIONS ON ETHNIC BARGAINING}

Institutionalist arguments identify different mechanisms through which partition is supposed to have a pacifying effect. The gist of the argument is that partition reduces hostility by simplifying postwar bargaining between the elites of a secessionist state and elites in the predecessor state. Chapman and Roeder base their analysis on such an argument. They view partition-by which they mean only the creation of a new state-as a solution that eliminates conflict by (1) strengthening the collective identity of the inhabitants of the secessionist re- 
gion constituted as a new state and reducing the claims of the rump state to its former territory and citizens; (2) eliminating causes for conflict such as differences in interests over government policies by minimizing the number of decisions that have to be made jointly by the central government of the rump state and leaders of the secessionist region; (3) raising the costs of escalating conflict, because the creation of a new state implies that the only possibility for escalation is waging a new war across an international border, or applying force through sanctions; and (4) giving both sides more visible and defensible military positions as the new state can more readily build the coercive institutions of a government, achieving a balance of capabilities. ${ }^{45}$

Despite the appeal of analyzing the institutional effects of partition, the logic of these arguments rests on a series of unstated, ad hoc assumptions linking institutional arrangements to conflict over identities, policy autonomy of governments, and warfighting capabilities.

For the institutionalist argument to work with respect to identity conflict, any separation must strengthen the identity of the secessionist region while reducing the rump state's claim to it. Nothing in the large literature on nationalism explains why a nationalist central government would cede its claim to the inhabitants of the secessionist region, let alone the territory, solely because a competing identity starts to develop there. Partition may in fact have the opposite effect, strengthening the central government's resolve to bring the territory back into the fold. Moreover, any institutional effect on identity would occur only in the (very) long run; hence this argument is of little use to guide the empirical analysis of the effects of partition in the immediate aftermath of civil war, which is the period of highest risk of recurrence.

Turning to governance, de jure partition does not, in fact, eliminate the involvement of the rump state in the internal affairs of the new state. Even a cursory reference to international relations theory suggests that sovereign states are not necessarily autonomous from one another. Basic factors such as geography play a role in determining the secessionist region's ability to govern itself without interference, regardless of the institutional arrangement. For example, a partition that creates a new, land-locked state might create a government with less autonomy than the de facto separation of a self-sufficient region with access to ports and well-developed infrastructure. The conditions under which the governance argument might apply need to be spelled out.

Similarly, military capabilities are not clearly linked to the institutional arrangements. Chapman and Roeder contend that autonomy presents the great- 
est threat of internal subversion to the rump state because the dissenting secessionist region remains physically within the unitary state. Yet governments (whether or not officially recognized) have long practiced subversion against their foreign enemies, fomenting dissent and protest, and financing opposition groups in neighboring states. Governments of the secessionist region, either under de jure partition or de facto separation, would retain this option.

Partition also need not enhance the capability of each entity to defend itself. An example that illustrates the point is Israel's seizure of the Golan Heights from Syria, which was deemed by military analysts to have given it a better defensive position. If the Golan Heights are eventually returned to Syria, Syria will have an improved defensive position against Israel not because an internationally recognized border will once again exist in that place, but because of the nature of the territory in question.

Even though the conferral of international legitimacy on the government of the secessionist region through partition allows it to build up its military capabilities, this need not imply that balance with the rump state can be achieved, and the same outcome can also occur in de facto separations. An illustration is the case of Cyprus, where the de facto separated Turkish Republic of Northern Cyprus, backed by Turkey's superior military, was able to thwart efforts by the Greek Cypriot-controlled sovereign government of Cyprus in 1997 to acquire a sophisticated surface-to-air missile system from Russia because installation of the system would upset the balance of power in the Greece-Cyprus-Turkey triangle. Military capabilities are shaped by patterns of international intervention, third-party guarantees, and superpower interests, not by the degree of international recognition of a political border.

\section{PARTITION IN THE CONTEXT OF A DYNAMIC MODEL OF CONFLICT}

Even if partition solves a conflict by separating populations that do not trust each other to cooperate in a postwar state, it can generate incentives for new identity or distributional conflicts in both the rump and secessionist states. By definition, in a country where partition creates social homogeneity along any salient social cleavage, there should be no more internal conflict between the partitioned groups. That seems to be the standard used to judge the effectiveness of partition by most pro-partition scholars. But this standard is based on a narrow concept of civil war. Partition can encourage competition over power or resources such that individuals sort themselves into groups with new ethnic or class identities, and new conflicts can arise between those new groups over the type of government, redistribution, or ethnic advantage. The only rea- 
sonable standard of the effectiveness of partition is one that takes into account the complicated ways in which partition can generate new conflict.

Several types of new conflict can occur following partition: conflict within the newly formed state over control of the government; ${ }^{46}$ conflict by a new group seeking to secede from the newly formed state either to rejoin the rump state or to create a new entity; ${ }^{47}$ and conflict between the newly formed state and the rump state (interstate conflict, if the new state has legal sovereignty). ${ }^{48}$ Also possible is conflict over control of the government in the rump state as nationalist groups challenge the government over the loss of territory to the secessionists, or conflict arising from the distributional consequences of per capita income loss associated with the loss of resource-rich territory. ${ }^{49}$ Finally, conflict may arise between the government of the predecessor state and other minorities that rebel as a result of secondary consequences of partition. ${ }^{50}$

46. The Irish Civil War (1922-23) followed the conclusion of a 1921 treaty establishing Ireland as an autonomous unit with self-government within the British Empire. Proponents of the treaty fought advocates of complete independence. See Joseph M. Curran, The Birth of the Irish Free State, 1921-1923 (Tuscaloosa: University of Alabama Press, 1980); and Bill Kissane, The Politics of the Irish Civil War (Oxford: Oxford University Press, 2005).

47. After partitioning of territory (and internal war between Kenyans and the British), ethnic Somalis in Kenya tried to secede to rejoin a "greater Somalia" in the Shifta War of 1963-67. The help that Somalia gave the rebels shows how these new conflicts can develop along several dimensions, because it led to tension between Somalia and Kenya. See Saadia Touval, "The Organization of African Unity and African Borders," International Organization, Vol. 21, No. 1 (December 1967), pp. 102-127; and Richard Hogg, "Pastoralism and Impoverishment: The Case of the Isiolo Boran of Northern Kenya," Disasters, Vol. 4, No. 3 (September 1980), pp. 299-310. Another example, but of the nonethnic variety, are the Yosu and Cheju-do rebellions in South Korea (1948-49). See Stanley Sandler, The Korean War: No Victors, No Vanquished (London: University College London Press, 1999); and Allan R. Millet, The War for Korea, 1945-1950: A House Burning (Lawrence: University Press of Kansas, 2005).

48. An example is the war between Ethiopia and Eritrea five years after their partition.

49. Nationalist backlash resulting from territorial loss has led to abrupt regime change. In Argentina, the junta fell after the Falklands war, as did the junta in Greece after the partition of Cyprus, and the military government of President Yahya Khan of Pakistan after the secession of East Pakistan.

50. Following the partition of India, tribal conflicts intensified with the influx of refugees, who displaced tribal people from their ancestral lands. The Nagas rebellion in 1956 is directly related to the 1947 partition, and insurgency in Tripura was triggered by the influx of Bengali refugees from what became East Pakistan following the 1947 partition and during East Pakistan's secession from Pakistan in 1971. Similarly, the Assamese insurgency resulted from rapid changes in the demographic balance between Bengalis and the outnumbered Assamese. See B.G. Verghese, India's Northeast Resurgent: Ethnicity, Insurgency, Governance, Development (New Delhi: Konark, 1997); Subir Bhaumik, "Negotiating Access: Northeast India," Refugee Survey Quarterly, Vol. 19, No. 2 (2000), pp. 142-158; Subir Bhaumik, "Insurgencies in India's Northeast: Conflict, Co-option, and Change," EWCW Working Papers, No. 10 (Washington, D.C: East-West Center Washington, July 2007); and Parkash Singh, "Demographic Movements: The Threat to India's Economy and Security," Low Intensity Conflict and Law Enforcement, Vol. 11, No. 1 (Spring 2002), pp. 94-115. 
Below, we offer a new empirical analysis that takes into account the datacoding issues we identified earlier.

\section{A Benchmark Analysis of the Effects of Partition}

In light of the importance of coding decisions in our reanalysis of Chapman and Roeder, we return to the crucial coding questions we identified earlier. We consider how partition and war recurrence should be coded and explore the consequences of limiting the analysis to ethnic wars or expanding it to include all civil wars.

\section{WHAT IS A PARTITION?}

A key coding question is if de jure and de facto cases of partition should be combined. Some authors expect the peace-inducing effect of partition to be associated only with de jure cases; others argue that sovereignty is not crucial for peace and what matters is the physical separation of hostile groups or the defensibility of the new territory. Whether these two subsets of partition should be combined depends on the theoretical mechanism that underpins the anticipated effect of partition. We find little theoretical justification for separating the two. Civil war is fought by groups against a state and, as the governments of new entities created by de facto separation, they are states in the Weberian sense; accordingly, they can face internal challenges and civil wars, much like juridically sovereign states. De facto partitioned states can behave like internationally recognized states in all but name. ${ }^{51}$ Moreover, the fact that some partitions are internationally recognized need not reflect a deeper level of hostility between the warring parties, and a concomitantly higher expectation that without separation a return to war would be more likely in those cases.

Although we argue for combining the two types, we nonetheless explore empirically whether results for de jure and de facto partitions are different. Using a new civil war data set that we compiled, we employ different lists of partition to capture all major differences in how partition is conceptualized

51. The Turkish Republic of Northern Cyprus is an example. Charles King also describes how Nagorno-Karabakh, Transnistria, Abkhazia, and South Ossetia "act in the international arena as if they were independent entities and cooperate with one another to a great degree," with this cooperation extending to security matters and pursuit of common stances in diplomatic relations with states. See King, "The Benefits of Ethnic War: Understanding Eurasia's Unrecognized States," World Politics, Vol. 53, No. 4 (July 2001), p. 542. For a cogent discussion of the differences between the de facto exercise of state power and the juridical notion of the sovereign state, see Robert $\mathrm{H}$. Jackson and Carl G. Rosberg, "Why Africa's Weak States Persist: The Empirical and the Juridical in Statehood," World Politics, Vol. 35, No. 1 (October 1982), pp. 1-24. 
and explore empirically the significance of these differences. ${ }^{52}$ We combine externally imposed partitions and successful secessions if they resulted from or coincided with civil war and code up to 22 partitions in the 145 civil wars included in our data covering the period from 1945 to 1999 (see supplement, pp. 1-8, for a detailed discussion of coding issues). To show that our conclusions are not the artifact of coding rules, we present results from both a "strict" and a "lenient" list of partitions. The strict version includes only 12 cases that most scholars would identify as either de jure or de facto partition following a civil war. The lenient version includes 10 other cases that may be considered ambiguous (either the partition or the war is ambiguous). The two lists are presented in table 2. The strict list should fit the partition advocate's notion of partition or secession as the outcome of civil war with 6 out of 10 cases characterized by extensive demographic separation. In the supplement (pp. 13-18), we examine results based on four other ways to code partition: three based on the lenient list but dropping de facto separations, prewar partitions, and both from the list; and a fourth coding only cases where partition resulted in a very high degree of physical separation of the warring ethnic groups. The main conclusion from our study is not altered by using these additional four partition lists, so we save those results for the supplement.

\section{WHAT IS WAR RECURRENCE?}

Civil wars are internal armed conflicts between the state and domestic challengers that leave large numbers of people killed in mutually harmful and relatively continuous fighting. A war ends when there is a military victory, a signed peace settlement, or a truce/stalemate that terminates the fighting. We code war recurrence two years after the war (norecur2) for all civil wars that started on or after 1945 and ended before 2000. All results in this article are robust to using a different civil war list and different rules for coding war recurrence. $^{53}$

We code different versions because the different studies use different concepts of war recurrence and coding this is not straightforward. A common definition of recurrence is a return to a previous condition. ${ }^{54}$ In the civil war literature, this is usually taken to mean that the same parties return to war over

52. We use the list of civil wars from Sambanis, "What Is Civil War?"

53. For robustness tests in the supplement, see pp. 19-35. We use data sets from James D. Fearon, "Why Do Some Civil Wars Last So Much Longer than Others?" Journal of Peace Research, Vol. 41, No. 3 (May 2004), pp. 275-301; and Barbara F. Walter, "Does Conflict Beget Conflict? Explaining Recurring Civil War," Journal of Peace Research, Vol. 41, No. 3 (May 2004), pp. 371-388.

54. See http://dictionary.reference.com/browse/recurrence. 
Table 2. "Strict" and "Lenient" Lists of War-Related Partitions in Civil Wars, 1945-2000

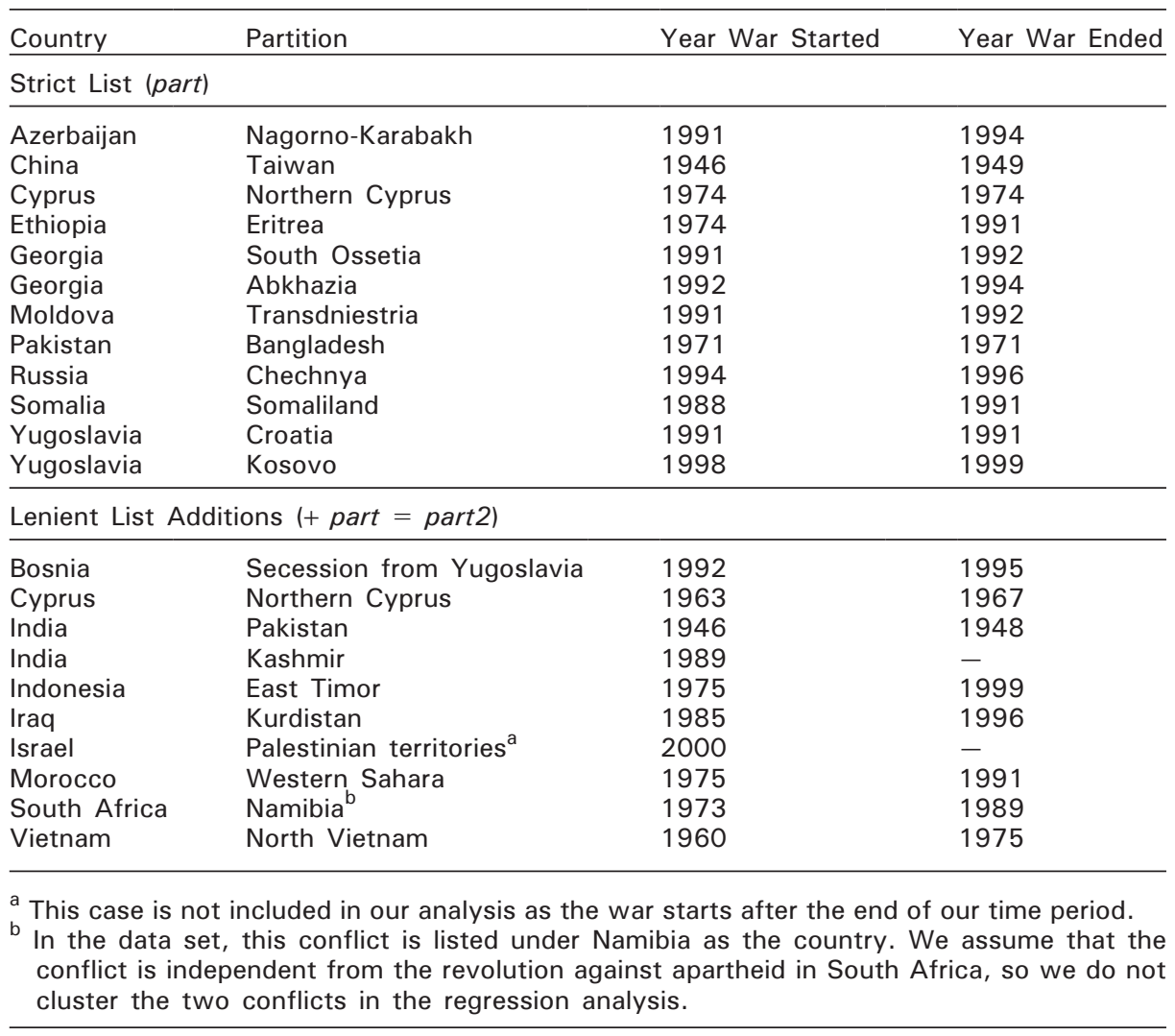

the same issues, as in Barbara Walter's study, which identifies only 14 cases of civil war recurrence in the Correlates of War list of civil wars. ${ }^{55}$ This way of conceptualizing and coding war recurrence, however, is deceptively simple, and can be complicated in a number of ways. First, how should we deal with time? If two ethnic groups fight, stop fighting, and go back to war after several decades, is this "a return to a previous condition" or is this a new war? In Walter's data set, despite nearly thirty years of peace separating the 1963 war between Hutus and Tutsis in Rwanda and the war that started in 1990, this is an instance of civil war recurrence. An implicit assumption here is that the "par-

55. Walter, "Does Conflict Beget Conflict?" 
ties" are the same—still Hutu and Tutsi-even though leaders and their interests may be different over time.

A second complication arises because of our specific concern with the effects of partition. If partitions can transform civil wars into international wars, then the appropriate concept of war recurrence would capture those cases of conflict transformation. Clearly, if partition results in the formation of a new state, and if there is complete separation of groups from the first war, then a second civil war between those groups is by definition impossible, so the only meaningful way to define recurrence is to include cases where interstate war occurs between partitioned groups. Thus, for example, following the partition of Eritrea from Ethiopia, war recurrence should be coded at the start of the Ethiopian-Eritrean war over lingering interstate boundary issues.

A third complication results from the possible precedent-setting effect of partitions. If the first war produces a partition and the creation of a new state, new security risks will arise in all affected countries. Whether secession triggers a war between the predecessor state and residual minorities in that state, or between the government of the secessionist state and ethnic minorities in that state, is the sort of information that is necessary for a full assessment of partition's consequences. Successful partitions may inspire other groups to start separatist wars, so focusing exclusively on recurrence of war between the same two (or more) groups over the same issues imposes a theoretically biased concept of war recurrence on the data. This is bound to influence assessments of the effects of partition by excluding some of the most significant security risks associated with it. ${ }^{56}$

In sum, coding civil war recurrence is often a matter of judgment, and many cases are ambiguous. Most civil wars are messy as new parties join the violence, fluid coalitions form at different stages of the war, and issues change over time. Once the war ends, even if the parties that had been active at the end of the war remain peaceful, new groups may be mobilized as a result of that war's outcome. Settlements may leave some groups aggrieved, whereas victories may result in repression, mobilizing new groups to challenge the state. If new violence starts between new groups in the immediate aftermath of a civil war, it is likely causally linked to some aspect of the previous war. ${ }^{57} \mathrm{We}$

56. For example, the Bangladeshi secession from Pakistan in 1971 is typically considered separate from the war in Baluchistan that started in 1973. But both the Baluchi claims and the Pakistani military's response may have been intensified by the Bangladeshi secession.

57. If a war ends in rebel victory but violence erupts immediately between the rebels and new groups that are threatened by this outcome, most data sets would not code the start of a new civil war but would lump it with the previous one. 
classify such cases as incidents of war recurrence, given the complexities of a distinction between "new" and "recurring" war. This is a conceptualization of civil war as something that happens to an entire society and not simply between the state and one social group. Given significant ambiguities in the cases, however, we also use a second version of war recurrence (norecur2_v2) and conduct extensive robustness tests using other ways of coding this variable (see the supplement, pp. 19-27).

A different way to measure postwar pacification is to focus not only on war, but more broadly on any (internal) armed conflict and purges of the civilian opposition, or mass human rights violations over the same period. Per the preceding discussion, such conflict need not be limited to the groups that had been engaged in the fighting. We refer to this variable as "residual violence" and code different versions of it (we present results from warnov2 in tables 3 and 4 here and results from other versions in the supplement, pp. 103-105). ${ }^{58}$ Our main source of information on deaths in lower-level conflicts for this version is the armed conflict database by UCDP $/ \mathrm{PRIO},{ }^{59}$ which provides annual data on minor armed conflicts (causing twenty-five deaths or more). This measure corresponds more closely to Chapman and Roeder's survival of peace variable. To adjudicate between rival theoretical claims, we compare results using this dependent variable to results with respect to civil war recurrence.

\section{EFFECTS OF PARTITION IN A NEW MODEL OF POSTWAR PEACE}

Using our coding of war outcomes, we can estimate the effects of partition in a model of postwar peace. We show results using both the strict and lenient lists of partitions (our conclusions are robust to any of the six lists of partition we have coded; to save space, we show other results in the supplement, pp. 1318). Control variables in our model are mainly drawn from Michael Doyle and Nicholas Sambanis's peacebuilding model, which analyzes peace as the outcome of hostility, local capacities, and international assistance. ${ }^{60}$ We control for the number of deaths and displacements resulting from the war (in logs); the number of factions; the presence of any peace mission (by the United Nations

58. The supplement also contains results from robustness checks of the warnov2_01 regressions contained in table 3. See pp. 62, 67-68, 71-72, 75, 78, 80-82.

59. Lotta Harbom and Peter Wallensteen, "Armed Conflict, 1989-2006," Journal of Peace Research, Vol. 44, No. 5 (September 2007), pp. 623-634; and Nils Petter Gleditsch, Peter Wallensteen, Mikael Eriksson, Margareta Sollenberg, and Håvard Strand, "Armed Conflict 1946-2001: A New Dataset," Journal of Peace Research, Vol. 39, No. 5 (September 2002), pp. 615-637.

60. Doyle and Sambanis, Making War and Building Peace. 
or other third party); dependence on primary commodity exports (exports as a percentage of GDP); the type of war (ethnic/nonethnic); the signing of a peace treaty; country-level ethnic fractionalization; per capita income (year prior to war start); and annual per capita income growth (year after war ends). We try other controls, such as war duration, effective development assistance, size of the government military, Cold War dummy, oil export dependence, colonial status, and region effects, and show results in the supplement (pp. 62-68). We refer readers to Doyle and Sambanis's book for a discussion of why and how these variables might affect war outcomes.

Country and war characteristics may affect both the chances for postwar peace and the likelihood that there will be a partition, so adding those controls should reduce the risk of omitted variable bias. Partitions have occurred more frequently in ethnoreligious wars, very bloody wars with many displacements, and countries with large ethnic groups, low levels of ethnic fractionalization, and a relatively higher level of development.

In table 3, we report results for two versions of our dependent variable (norecur2, norecur2_v2) for both strict and lenient versions of partition (part, part2) for all civil wars. ${ }^{61}$ We show results for all wars and repeat the analysis for ethnic wars only in table 4 . Standard errors are clustered by country (all former Soviet Union and former Yugoslavia countries are clustered) due to lack of independence of observations within clusters.

Partitions do not have the anticipated positive and significant effect on postwar peace. The coefficient sign for partition in these regressions is always far from statistically significant and sometimes changes sign depending on which list of partitions is used. The picture is similar if we use the alternative versions of the dependent variable (see the supplement, pp. 23-27, for differently coded cases and results), or if we look at outcomes five years after the war ends (see the supplement, p. 22) ${ }^{62}$ The main predictors of a return to war are local capacities: higher per capita income and income growth reduce the risk of another war, whereas dependence on primary commodities increases it. This is consistent with results from studies of civil war onset, but inconsistent with security dilemma arguments.

An interesting new result is that higher ethnic fractionalization lowers the chance of postwar peace. This may be caused by the new fractionalization

61. Our replication folder includes commands for simple Pearson correlation statistics between different outcomes and all versions of the partition variable for both ethnic and all wars as well as different coding of ethnic wars.

62. Using a different list of civil wars, we see a negative and significant result for the effect of partition on war recurrence. See the supplement, pp. 32-35. 


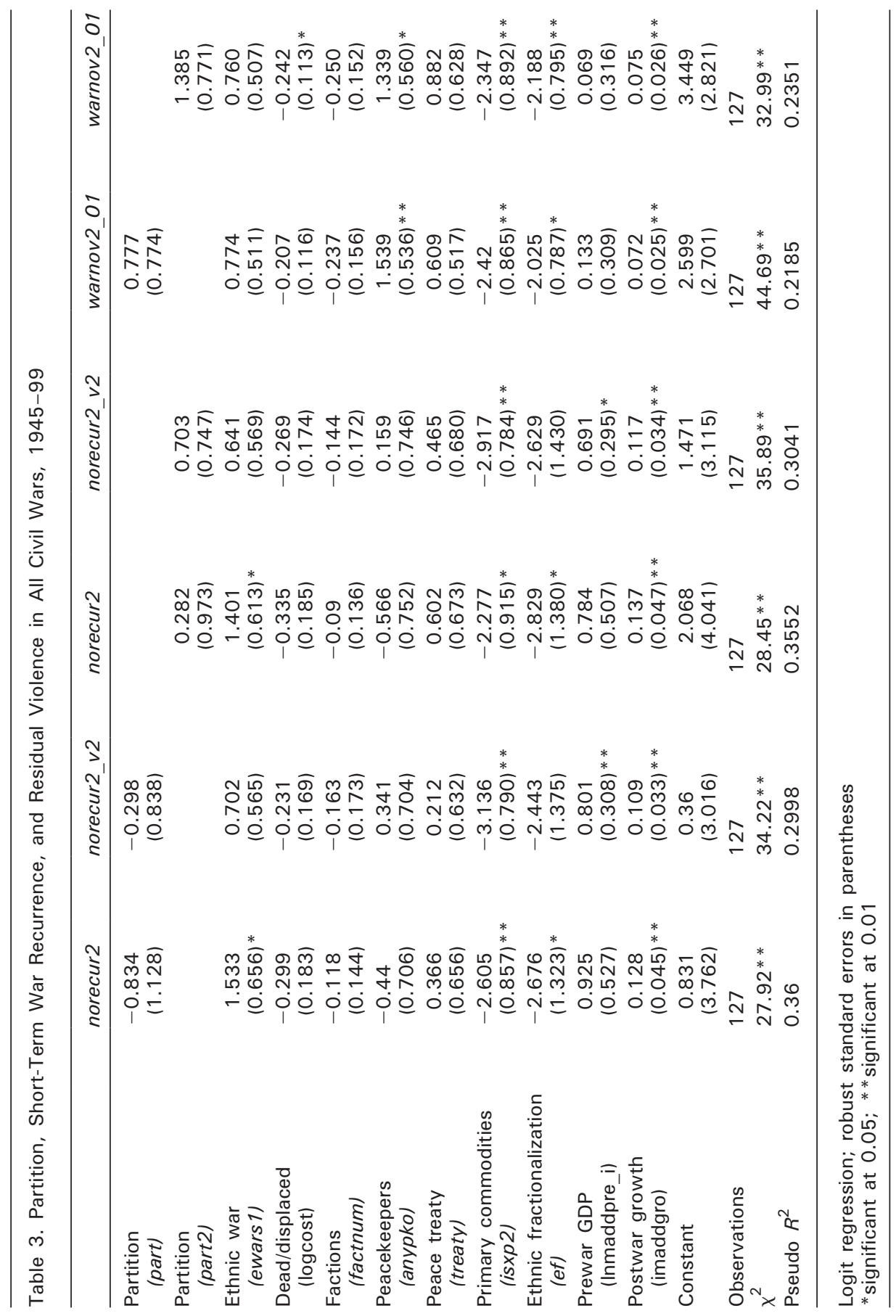


measure we use here. The result seems to confirm the intuition that violence hardens identities, making interethnic cooperation after civil war difficult. ${ }^{63}$ Although on the surface this appears to support pro-partition arguments, countries born out of violent partition need not be less ethnically diverse than their predecessors, so the risk of a new war in those countries because of their ethnic makeup need not be lower. Ethnic fragmentation in South Africa and Namibia are about the same (0.88 and 0.73 , respectively, using James Fearon's measure $\left.{ }^{64}\right)$. Ethiopia and Eritrea are also fairly close $(0.76$ and 0.65 , respectively). ${ }^{65}$ In some cases, partition created more homogeneous states than their predecessors (Bangladesh's fractionalization index is 0.22 compared with 0.53 for Pakistan). But these differences depend on how we measure fragmentation: India's linguistic fragmentation is much higher than Pakistan's (0.81 vs. 0.53), but it is slightly lower if we look at religious fractionalization (0.34 vs. 0.36); and its ethnic polarization, which could be more strongly correlated with civil war risk, is much lower than Pakistan's (0.35 for India vs. 0.70 for Pakistan). ${ }^{66}$

63. The "hardening" argument would not apply if ethnic fractionalization also increased the initial risk of civil war-not just war recurrence, which is a result found by Håvard Hegre and Nicholas Sambanis, "Sensitivity Analysis of Empirical Results on Civil War Onset," Journal of Conflict Resolution, Vol. 50, No. 4 (August 2006), pp. 508-535. Different heterogeneity and polarization measures have been shown to correlate with civil war. See David Siroky, "Heterogeneity, Secession, and Violent Conflict," unpublished paper, Duke University, 2008, for an insightful analysis and a new measure of heterogeneity.

64. James D. Fearon, "Ethnic and Cultural Diversity by Country," Journal of Economic Growth, Vol. 8, No. 2 (June 2003), pp. 195-222.

65. Using ethnic fractionalization data from Alberto Alesina, Arnaud Devleeschauwer, William Easterly, Sergio Kurlat, and Romain Wacziarg, "Fractionalization," Journal of Economic Growth, Vol. 8, No. 2 (June 2003), pp. 155-194, we find that ethnic fractionalization in pre-partition Ethiopia is similar to that of postpartition Ethiopia and Eritrea, and that ethnic fractionalization in a unified South Africa is quite similar to that of postpartition South Africa and Namibia. We calculate ethnic fractionalization according to the formula used in ibid.: $F R A C T_{j}=1-\sum_{i-1}^{N} s_{i j}^{2}$, with the subscript $j$ denoting the country and $s_{i j}$ being the share of group $i(i=1 \ldots N)$ in that country.

For a unified South Africa, we make a composite from the ethnic group data for both countries (for South Africa in 1998 and Namibia in 1995) contained in ibid. and use total population data for each country found in the U.S. Department of State Country Background notes for the relevant year. Fractionalization for the composite unified South Africa is 0.7701, while fractionalization in postpartition South Africa and Namibia is 0.7517 and 0.6333 , respectively.

For pre-partition Ethiopia, we take ethnic fractionalization data from Alesina et al., 0.7235 in 1983. The authors also provide postpartition fractionalization for Eritrea, as 0.6524 in 1998 . We calculate the postpartition ethnic fractionalization of Ethiopia as 0.7974 in 1994, using group shares of the population from the 1994 Ethiopian Census, taking all ethnic groups having at least 2.4 percent of the population (because in the data for pre-partition Ethiopia, the smallest group-share of the population for the groups included is 2.4 percent). Given that our pre-partition fractionalization data are ten years prior to partition, we cannot say with certainty that ethnic fractionalization in Ethiopia increased following partition. At a minimum, however, it is highly unlikely that it decreased with partition. Additional details available from the authors upon request.

66. Polarization data are taken from José G. Montalvo and Marta Reynal-Querol, "Ethnic Polarization, Potential Conflict, and Civil Wars," American Economic Review, Vol. 95, No. 3 (June 2005), pp. 796-816. 
Partition advocates suggest that only ethnic or secessionist wars should be included in the analysis, though there is no strong theoretical justification to exclude nonethnic wars. We nonetheless checked that results do not change substantively if we restrict the cases in this way. We do not run the model on secessionist wars because there are only 4 peace failures out of 49 secessionist wars (most partitions do take place in secessionist wars; adding a control for secessionist wars, however, does not affect the results). The breakdown of successes and failures across ethnic wars is slightly less skewed, though it depends on which version of the ethnic war category we use. Our strict coding rule produces a list of ethnic wars that does not correlate highly with others (about 52 percent with Fearon's list). If we limit analysis to that list, we would lose 40 percent of partitions. Thus we use Doyle and Sambanis's list of ethnic wars with 4 cases recoded. The results are presented in table 4 . There is again no positive and significant effect of partitions, except for an unstable positive effect with respect to residual violence (column 6).

\section{ROBUSTNESS OF RESULTS}

Extensive sensitivity tests confirm that there is no significant positive correlation between partition and no war recurrence. For all models from table 3, bias-corrected bootstrapped standard errors for partition are extremely large and include zero. ${ }^{67}$ Results on the effects of partition do not change substantively when we add controls and drop ambiguous cases of civil war (28 cases), influential observations, cases of government victory, ${ }^{68}$ and subsets of the data

67. Underlying our inferences about short-run peacebuilding are some assumptions about the parameters' sampling distribution from a population of data, which we have assumed to be $\chi^{2}$-distributed. This allows us to test hypotheses based on parameter estimates obtained from logistic regression. But with a small sample, the sampling distribution of the statistics of interest and the parameter estimates may not match the assumed $\chi^{2}$ distribution, so some of our inferences may be mistaken. We can check this with bootstrapping-a nonparametric method of making inferences about population parameters based on estimates of a statistic's sampling distribution. The sampling distribution is obtained by resampling the data with replacement many times (we use 1,000 repetitions), thus treating the observed data as if it were the population. Thus, the bootstrap depends critically on the assumption that the observed distribution is a good approximation of the population distribution. We then use that distribution to estimate the standard error of the statistic of interest (the coefficient for the explanatory variables in our model) and to obtain confidence intervals.

68. Readers might object that the effects of partition should be compared only to cases of powersharing because military victories are thought to be more stable than other war outcomes and they may well be more repressive (hence even if there is no further civil war, human welfare may be lower after a victory). Victories, however, are not necessarily more stable after negotiated settlements (see Doyle and Sambanis, Making War and Building Peace), and partitions are a type of victory by the rebels. We nonetheless drop cases of government victory as a robustness test (supplement, pp. 76-78). 


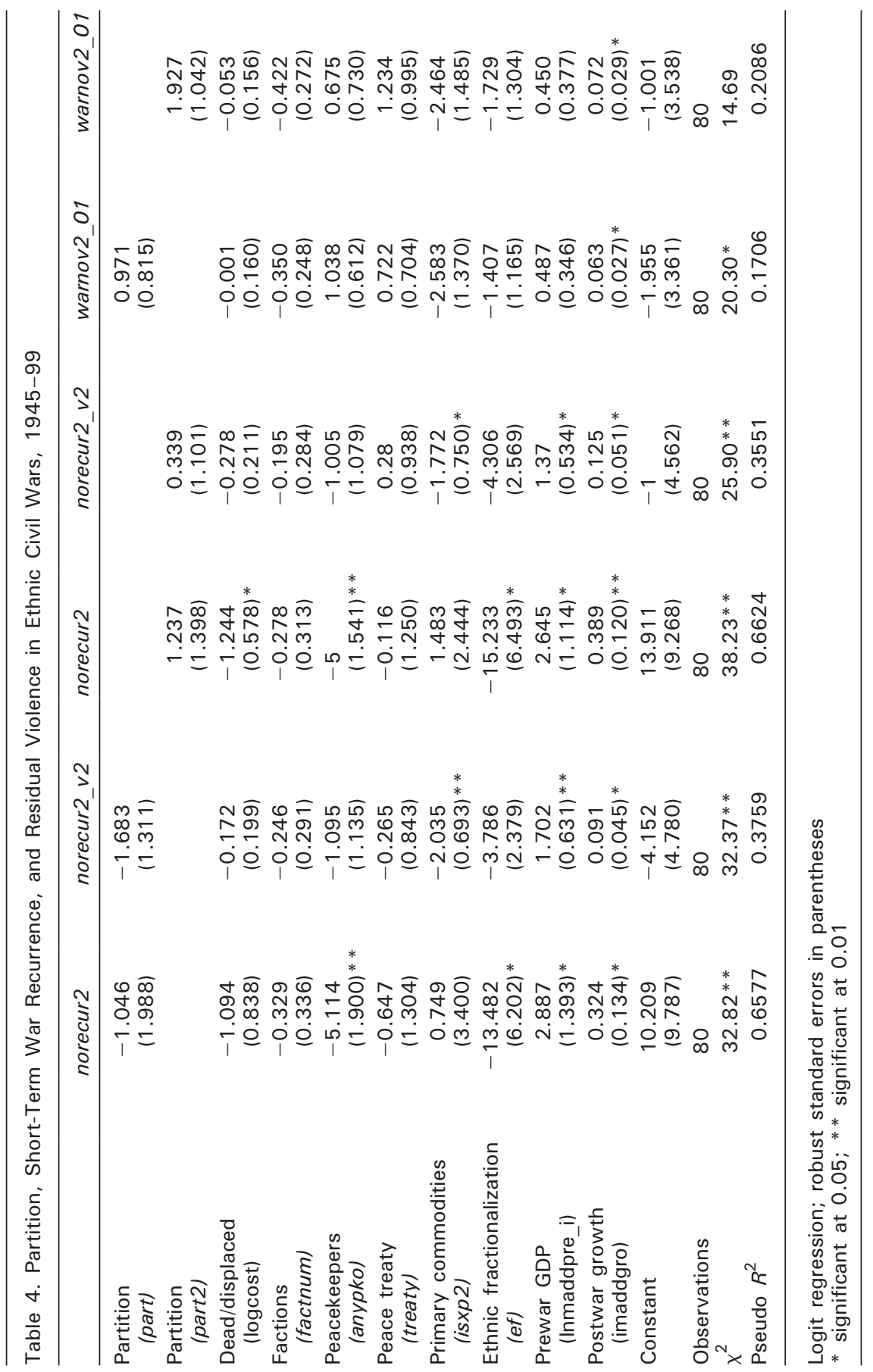


that may make them different from the rest of the cases in ways not captured by the model. ${ }^{69}$

Results are also not an artifact of the short time horizon we use to evaluate outcomes. Using survival analysis and measuring peace in months from the end of the war until the end of analysis time in December 1999, we confirm that there is no positive effect for partitions. ${ }^{70}$

A complication is that partition does not occur at random and that it has occurred more frequently in countries with higher prewar per capita income, but with sharply lower postwar growth and bloodier wars (and, to a lesser degree, shorter wars). In light of the apparent selection of partitions on observed covariates and the possibility that partition's effects may vary in different ranges of other covariates, we reestimate the effects of partition using matching. Matching estimates of treatment effects relax some of the parametric assumptions that underlie the logistic regressions presented earlier. ${ }^{71}$

Estimation is based on matching on covariates using Jasjeet Sekhon's GenMatch software. ${ }^{72}$ We assume that partition can be thought of as a "treatment" (with any partition constituting the treatment). Under certain assumptions, matching can estimate the causal effect of partitions, by comparing outcomes in the treatment group (cases of partition) and the control group (no partition) if these cases are fairly similar with respect to observed covariates and if no significant variables have been omitted from the model. Matching estimates reinforce the picture we obtain from the logistic regressions. For all civil wars, strict partition has a negative average treatment effect on the treated cases $(\mathrm{ATT}=-0.33$, with $p$-value $=0.07$ ). Covariate balance is im-

69. We drop coups, genocides, and geographical regions one at a time, as well as all but the first observation for each country unless civil wars in the same country are too far apart or are clearly independent. See the supplement, pp. 76-83.

70. We prefer the short-term outcomes for reasons explained in the supplement. See results from the duration analysis in the the supplement, pp. 116-120. Survival analysis can be used to examine the duration of the peace beyond the two-year mark and accounts for right-censoring, offering an estimate of the risk of peace failure at time $t$ given that failure has not occurred until then. The dependent variable is now "time until peace failure," a continuous variable that measures peace duration in months from the end of the war until the peace fails or until analysis time ends.

71. All parametric models select (by assumption) a functional form to optimize the model's fit to the observed data. The models that we have estimated thus far rely on an assumption of linearity in the latent variables. Yet, some of the explanatory variables in the model are correlated and the effects of partition may differ in different ranges of some covariates. Due to the small number of partitions, we do not show results from regression models with interactive effects. Model fit statistics show more support for models without interactions (see the supplement, pp. 89-96). We use matching to deal with the potential selection of partition on observables (i.e., the set of covariates included in the model). Matching relies on the assumption of no omitted variable bias.

72. Jasjeet S. Sekhon, "Multivariate and Propensity Score Matching Software with Automated Balance Optimization: The Matching Package for R," Journal of Statistical Software (forthcoming). 
proved dramatically by GenMatch for treatment and controls, though we do not set a narrow caliper because we cannot match all treated observations within 1 standard deviation of each covariate. ${ }^{73}$ For ethnic wars only, using the lenient version of partition, we still obtain negative ATT estimates $(-0.17$, with a $p$-value of 0.23 ) with good balance on the covariates (supplement, pp. 110112).

Using the same matching method on Chapman and Roeder's data and model, which includes only the seven de jure partitions on their list with only a single case of peace failure among them, we find no significant treatment effect for partition (the ATT estimate is 0.29 , with a $t$-statistic of 1.08 ; see the supplement, pp. 113-115). We drop autonomy and separation from the model, because these are competing and mutually exclusive treatments so we should not match on them. In addition, we do not restrict the distance within which it is acceptable to make matches, because no matches can be made within the default caliper distance. Matching improves balance in all but one of the covariates, and there are no statistically significant differences in the means of any of the covariates in the two groups (minimum $p$-value $=0.22$ ).

Matching relies on SUTVA, or the Stable Unit Treatment Value Assumption. ${ }^{74}$ SUTVA is a requirement for noninterference between units. Specifically, treatment assignment must be independent of potential outcomes for all other units. To make this concrete, if the civil war in Iraq ends through a partition, the outcome of that partition (whether or not there is a return to war) must be independent of whether or not there have been partitions in Yugoslavia or other countries. ${ }^{75}$ This is a reasonable assumption for our data set. What may occur in practice is that partition in Yugoslavia may have influenced the probability that Iraq will be partitioned by shaping international attitudes toward partition, so treatment assignment in Iraq and Yugoslavia are related. This is not a SUTVA violation. It is unclear what lessons different countries draw from outcomes of prior partition, as partitions in different countries affect their interests in unique ways. ${ }^{76}$ But the influence of past partitions could pose an inferential problem, which we discuss below.

73. Detailed estimates and balance statistics are reported in the supplement, pp. 106-109.

74. Donald B. Rubin, "Bayesian Inference for Causal Effects: The Role of Randomization," Annals of Statistics, Vol. 6, No. 1 (January 1978), pp. 34-58.

75. In other words, we assume that treatment values are stable for each country-war-there is an outcome under partition and an outcome under no partition-and these treatment values are invariant to whether partition occurred after other country-wars.

76. A SUTVA violation might occur if two countries, A and B, are partitioned, and civil war recurs in country A and that war spreads to country B, leading to renewed war in B. A different selection problem might arise because some cases enter the sample only after certain outcomes, such as a 
Another assumption underlying matching estimates of the effects of partition is that partition can be conceptualized as a homogeneous treatment variable. A key assumption of matching would be violated if the treatment is heterogeneous across units (in an experimental setting, this would amount to a different dose or a different treatment type being given to different subjects). In political science applications, where matching is used to estimate the causal effect of an international policy in different countries, this is a problem that arises in virtually all studies because policies are not implemented identically in all countries. Here, we must assume that partition is a unified treatment, which means that we assume that there are no inherent and substantive distinctions between different forms of partition, such as de facto or de jure partitions. We discussed this point above and argued that there is no reason to assume that the effects of these two types of partition are significantly different. As a practical matter, we show in the supplement matching estimates obtained by breaking up the partition list into narrower subsets of cases. We quickly run into a small- $n$ problem in doing so, however. The small number of cases implies that inferences about the causal effects of partition cannot be based solely on statistical analysis, which is why we provided a discussion of the premises and assumptions underlying common theoretical arguments for partition to determine which arguments are plausible. More fine-grained theoretical modeling and systematic case analysis is needed to supplement the statistical analysis of the effects of partition.

In addition to the complications with matching estimation discussed above, there are at least two other limitations to our attempt to estimate the effect of partition using quantitative methods. First, our analysis treats partition as an exogenous variable. This is a common assumption in previous studies. The outcomes we study occur chronologically after partition, but it is possible that we have omitted from the model significant determinants of partition that also affect war recurrence. This would bias estimates and invalidate causal inferences made on the basis of the regression models presented earlier. To relax the exogeneity assumption, an instrumental variables model should be estimated that is identified by the inclusion of a variable that explains some of the variation in partition occurrence without having any other direct or indirect effect on the outcome..$^{77}$ We do not believe that such a variable can be found. Increasingly, econometric research questions the validity of instrumental variables re-

failed partition that results in war. We deal with this in the supplement by dropping all but the first civil war in each country and the results are qualitatively the same for two-year and five-year outcomes even though we end up with only ninty-two cases (see the supplement, pp. 82-83). 77. The only study to date that has tried to model the possible endogeneity of partitions by estimating an instrumental variables model of war recurrence is Sambanis, "Partition as a Solution to 
gression in cross-country comparisons such as ours. ${ }^{78}$ Although we have no solution to this problem, the risk of omitted variable bias should be attenuated by the inclusion of controls that the literature has found to be associated with peacebuilding outcomes (see the supplement for results of our tests of robustness to model specification changes). Our analysis serves as a benchmark for this literature, because it utilizes a data set that is sensitive to the conceptual and practical complexities of coding key variables and because the statistical results hold up using different estimation methods. But like the authors of all prior studies, we cannot claim to have identified the precise causal effect of partition.

Second, partitions may have demonstration effects, which would create a different inferential problem. Groups seeking greater self-determination may decide to fight a war after observing whether or not groups in other countries gained international support for partition after starting a civil war. Fearon analyzes this precedent-setting problem, using the Kosovar rebellion as an example. ${ }^{79}$ This case is a plausible example of a civil war that might not have happened had the rebels not anticipated that they could successfully secede from Serbia given the international community's prior endorsement of the secessions of Bosnia and Croatia. Indeed, successful secession might embolden other groups to challenge the state. Although there is some evidence that rebellions within the same country are linked in this way, the international diffusion effect of partitions is for the moment more of a theoretical claim than an empirical result. If it is demonstrated that these precedents cause new civil wars in other countries, then this would present a problem for the analysis we have presented, but our overall argument that partition does not have broad pacifying effects would actually be strengthened. These diffusion effects, however, would force us to shift our focus from civil war recurrence in specific countries to a broader inquiry of the effect of partitions on world order.

\section{Conclusion}

Once political conflicts turn violent, their resolution becomes harder. This is true with respect to civil wars of all types. The risk that war will recur soon af-

Ethnic War." The instruments used in that study, however, are unlikely to satisfy the exclusion restriction.

78. N. Gregory Mankiw, "The Growth of Nations," Brookings Papers on Economic Activity, Vol. 1, No. 1 (1995), pp. 275-326; and Thad Dunning, "Model Specification in Instrumental-Variables Regression," Political Analysis Vol. 16, No. 3 (Summer 2008), pp. 290-302.

79. James D. Fearon, "Separatist Wars, Partition, and World Order," Security Studies, Vol. 13, No. 4 (July 2004), pp. 394-415. 
ter its end is significant. Peace transitions are nonlinear processes: one step forward is frequently followed by two steps back. Peace treaties are often not implemented, and even when they are, they can fall short of restoring order. In light of these difficulties, scholars and policy analysts have been looking for self-enforcing solutions to civil war, if reconciliation and conflict transformation are unlikely outcomes. Partition might provide a solution to some wars if it provides a measure of self-enforcement or conflict transformation that is otherwise unattainable. ${ }^{80}$

Empirically, the question has not been settled, but the best available evidence shows no significant association between partition and postwar stability, defined as a lower risk of a return to war. For partition to outperform other outcomes, including regional autonomy, federalism, and unitary government with minority rights provisions (or even without such provisions), it has to be shown that all these outcomes are clearly less stable than partition and less desirable by some common standard. In this article, we considered war recurrence to be that standard, but a broader concept of human welfare might also be used. Theoretical arguments have been made on all sides, but nearly all arguments are incomplete and their premises are often flawed.

It may be that only certain types of partitions work-those that result in the establishment of a new state, with population transfers that leave none of the warring groups in each other's state, and societies that are ethnically homogeneous with no new distributional conflicts caused by the partition and no destabilizing regional effects that can transform internal conflicts to external, regional conflagrations.

How many partitions meet these ideal conditions? There have been very few, if any. Thus, the empirical record cannot help researchers assess the effects of an idealized form of partition, and we are left with the task of assessing the effects of partitions as they have actually happened. In partitions followed by successful peace transitions, confounding factors make inference difficult. Turkey's massive standing army dwarfs the Cypriot National Guard; India separates Pakistan and Bangladesh; Russian troops are stationed in Abkhazia; unusual international pressures were applied on Indonesia to let East Timor go. Thus, empirical assessments are necessarily tentative, especially given the contingent nature of historical outcomes. Namibia is a case in point: it is

80. Following a career of conflict generation and conflict resolution, however, Henry Kissinger warned that "above all, one has to understand that almost no problem has [a] final solution. In diplomacy, every so-called solution is an admissions ticket to another set of problems." Quoted in Isaac Arnsdorf, "Kissinger Speaks on U.S. Policy in M. East," Yale Daily News, December 7, 2007, http://www.yaledailynews.com/articles/view/22748. 
now an example of a successful partition, but it threatened to become a bad example because of the near-secessionist war in the Caprivi strip when the alliance between SWAPO (the ruling South West African People's Organization) and CANU (Caprivi African National Union) broke down ten years after independence.

The right standard by which to judge partition is in itself an interesting theoretical question with deep normative implications. Even if partition prevents the recurrence of internal and external war, the population transfers that idealtype partition requires cause suffering of a different kind. It is not easy to compare the welfare implications of reduced war risk to mass human rights violations. Ethnic cleansing, once considered a humane way to manage conflict, has fallen out of favor. In many ways, partition just takes the problem and calls it a solution.

An assessment of pro-partition claims must first scrutinize the basis for theoretical arguments that partitions are the most stable outcome to (ethnic) civil war. We have argued that key premises of pro-partition arguments are unproven and that more research is needed to determine if (1) violence hardens ethnic identities to a greater extent than nonethnic identities; and (2) violence escalation is faster or more intense in wars organized around ethnicity. These claims underlie the assumption that partition is a solution that is tailored to ethnic wars. If the claims are false and partition can be a solution that also applies to other types of civil wars, then partition cannot be the only possible solution to civil war, given that many wars have ended successfully without partition. A next step is to identify the observable implications of these arguments and test them empirically. For example, if war makes it harder for ethnic groups to coexist, then it is reasonable to expect to see some form of partition following civil war in more ethnically fragmented societies. Empirically, this is not true: partitions have not occurred more often in more fractionalized countries. Is this a question of limited supply (barriers to the international recognition of partition) or a question of demand (few groups actually wanting to secede)?

The security dilemma argument that has been used to support pro-partition claims is interesting, but the argument also applies to nonethnic groups as long as they are threatened and there is local knowledge of the relevant political affiliations of individuals. If credible commitment problems are the main source of postwar instability that partition is intended to resolve, and if commitment problems are commonplace, then the effects of partition should not be limited to ethnic wars and its effects should be analyzed by comparison to all other outcomes in all civil wars, as we have done in this study. Such a com- 
parison reveals that peace can be built without partition or decisive military victory, and it can be based on a negotiated settlement supported by United Nations peacekeeping and other external assistance.

The "institutional bargaining" model also offers weak foundations for arguments in favor of de jure partition as a solution to civil war. De facto partitions can fulfill the functions of internationally recognized states and can be as stable as de jure partitions. Legal recognition does not transform identities in the short run; it does not make borders defensible; and it does not guarantee that allies will assist a state that is attacked or that foreign aid will be available to offset economic risk.

World history since the emergence of the nation-state suggests that partitioning territories and creating new, more homogeneous states may not make the world more peaceful. At the limit, if ethnic diversity drives conflict, if all states are partitioned into ethnically homogeneous nation-states, the risk of intrastate conflict should decline as the risk of interstate conflict goes up. Institutional arguments assume that contentious identities will be quickly transformed by partition, whereas security dilemma arguments assume that contentious identities cannot be transformed. Yet neither argument has dealt with the institutional effects of partition on ethnic identity appropriately; both assume away the problem that new identities and distributional conflicts can be created by partition. Partition can increase the risk of violence by empowering ethnic elites if there are lingering territorial disputes, by weakening the status of residual minorities and forcing them to rebel, by activating new ethnic or ideological cleavages, by weakening the economic position of the rump or secessionist state, or by forcing contests over the control of the regime in the secessionist state.

Under some conditions and with respect to a limited set of goals, partition may work. What are the preconditions for success? What is the right measure of success? How can the international community know when to support and when to oppose partition? These are the questions that should drive the ongoing debate on the effects of partition after civil war. 